\title{
聴覚ターゲットにおける \\ Fittsの法則の検討
}

○大倉 元宏, 池上 敦子 (成蹊大学・工学部)

Prediction of positioning time for auditory target using Fitts law OMotohiro Ohkura, Atsuko Ikegami (College of Tech., Seikei Univ.)

1.はじめに

最近のコンピュータとューザのインターフ エースは”W I M P S (Window, Icon, Menu and Pointer systems)"という言葉で代表さ れるように，ますます視覚依存性を高めてい る。このような動向はコンピュータを仕事や 意思伝達の手段として活用している視覚障害 者にとっては全く不利といわさるを得ない。 本研究では視覚表示の聴覚表示への代替を図 る研究の一環として，聴覚ターゲットに対す るマウスによるポジショニングタイム（P T ） についてFittsの法則の適用可能性を検討した。

\section{1 被験者}

\section{2. 方 法}

被験者は30名（年㱓21〜 40才）で, 大学生 28 名, 教員 2 名であった。いずれるコンピュ 一タの使用経験を有している。

\section{2 実験装置と実験変数}

実験装置は，パーソナルコンピュータ（PC -9801DA, NEC; 以下 P C と記す)，P C 内蔵の F M 音源, 規則音声合成器 (音次郎pro, 又伤口 こクス）およびマウス（ミッキーハトット比=8、デフォルト值） であった。C R T ディスプレイ上に図 1 に示 すような隣接した 8 個（縦 $2 x$ 横4）の正方形マ スとマウスカーソル (矢印) が出力される。 それぞれのマスには図にみられるように1か ら 8 までのラベルが割り振られている。マウ スカーソルが縦横の境界線を通過すると, そ
れぞれ異なる音程の通過音（持続時間 $1 / 6$ 秒） が出力される。マウスカーソルは 8 個のマス 内のみ移動可能で, 外枠に接触した際には, 境界線通過音とは異なる音が出力される。こ

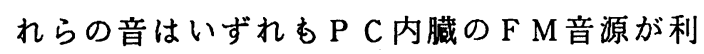
用された。さらに、マゥスの左ボタンクリッ クにより，カーソルのあるマスラベルが合成 音で出力される。正方形マスのサイズを実験 変数とし，一辺の長さが $15,25,35 \mathrm{~mm}$ (ディス プレイ上）の 3 条件を設定した。

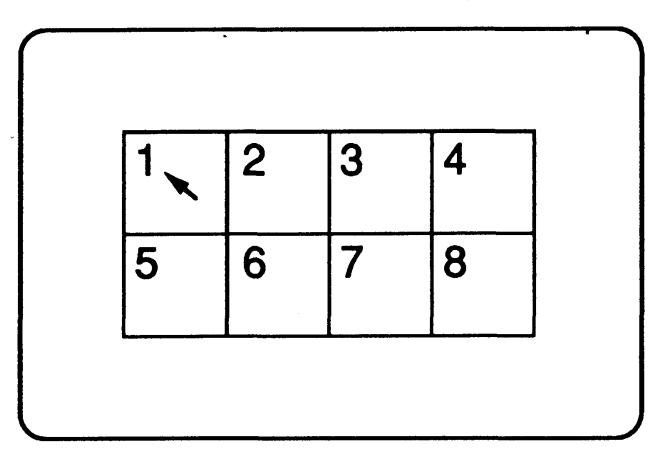

図 1 実験画面

\section{3 手 続}

アイマスクを装着した被験者には，指定さ れたマスサイズにおいて20試行, 実験者より 口頭で指示されたマスへできるだけ速く正確 にカーソルを動かし，マウスの右ボタンをク リックすることを求めた。20試行のなかには 4 種類の移動距離（マス単位で測って, 最小 1 , 最大 4 ; 視覚情報をむたない被験者は水 平と垂直の動きを組み合わせてカーソルを移 
動させると仮定）がランダムな順で，等頻度 ふくまれている。3つのマスサイズの提示順 は全部で 6 通りあり，それぞれに被験者を 5 名ずつ割り振った。なお，実験に先だって被 験者は各条件において視覚情報なしでのマゥ スの操作に十分慣れた。

\section{4 测定項目}

実験者による移動先の指示後, マゥスカー ソルが $5 \mathrm{~mm}$ 以上移動してから右ボタンが押さ れるまでの時間（0.1s単位）とそのときのマ スラベルが記録された。ただし，マスラベル の合成音出力中は所要時間計測は一時中断さ れる。

\section{3. 結果と考察}

被験者はマゥスカーソルを水平と垂直の動 きの組み合わせで移動し，仮説は適切である ことが確認された。

P T はWelfordの修正式にあてはめた。同式 は $\mathrm{PT}=\mathrm{alog}_{2}(\mathrm{D} / \mathrm{S}+0.5)+\mathrm{b}$ (ただし，D，多ゲッ までの距離; $S$, 夕ーゲットの大きさ; $\mathrm{a}, \mathrm{b}$ は定数）で あらわされる。 $\log$ の項は困難度を示す指標

(単位はbit) である。式から分かるように, 本実験における困難度は, マスサイズに依存 せず，距離のみによって決まる。マス単位で 測った距離 $1 ， 2 ， 3 ４$ において困難度はそれ ぞれ $0.59 ， 1.32 １ .81 ， 2.17$ bitsとなる。

被験者ごとに各マスサイズ・困難度条件の $\mathrm{P} T$ を抜き出し，それらの中央值をその被験 者の当該マスサイズ・困難度条件の代表值と した（誤ったマスを選択した場合には，その $\mathrm{P} \mathrm{T}$ は捨てないで，その移動距離に基づく困 難度条件に入れた）。この操作によって各マ スサイズ・困難度条件ごとに30個の中央值が 求まり，その平均値を当該マスサイズ・困難 度条件の代表值とした。図 1 はこの值を用い て，P T と困難度との関係を示したものであ る。マスサイズごとの回帰直線方程式と寄与 率は表 1 の通りである。寄与率は97〜99\% 極めて高く, 回帰線の傾き, 切片とも 3 つの
マスサイズで接近している。各困難度条件ご とに3つのマスサイズについて平均値の差の 検定を行ったところ有意な差は認められなか った。以上のことは, 今回設定したような聴 覚ターゲットについてもFitsの法則が成り立 つことを示している。

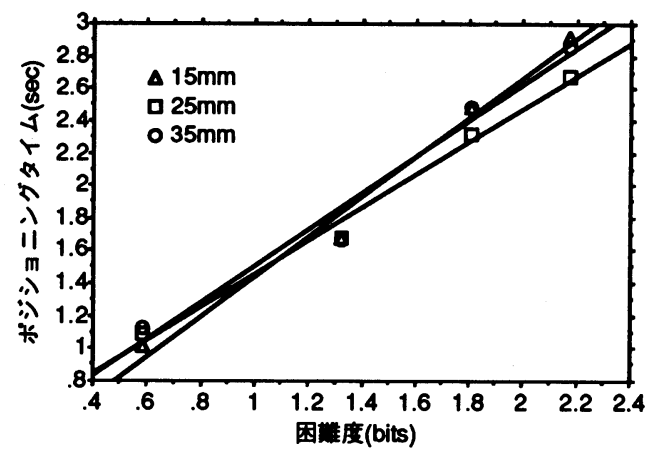

図 1 ポジショニングタイムと困難度

表 1 回帰直線方程式と寄与率

\begin{tabular}{|c|c|c|}
\hline マススサイズ & 回帰直線 & 寄与率 \\
\hline $15 \mathrm{~mm}$ & $P T=1.23 \mathrm{H}+0.22 \mathrm{~s}$ & $98 \%$ \\
\hline 25 & $\mathrm{PT}=1.02 \mathrm{H}+0.44$ & 99 \\
\hline 35 & $\mathrm{PT}=1.12 \mathrm{H}+0.38$ & 97 \\
\hline
\end{tabular}

表 2 は30名の被験者がそれぞれのマスサイ ズ・困難度条件で犯した誤選択の総数を示し たすのである。誤選択数は最すマスサイズの 小さい条件 $(15 \mathrm{~mm})$ で著しく数が多くなって おり，位置制御の難しさをうかがわせている。 また, 困難度とはいわゆるU字形の関連を呈 している。

表 2 各マスサイイ゚・困難度条件での誤選択数

\begin{tabular}{|c|c|c|c|c|c|}
\hline \multirow{2}{*}{$\begin{array}{l}\text { マरサイイ⿱ } \\
(\mathrm{mm})\end{array}$} & \multicolumn{4}{|c|}{ 困難度（距離） } & \multirow[t]{2}{*}{ 計 } \\
\hline & 1 & 2 & 3 & 4 & \\
\hline 15 & 14 & 15 & 9 & 10 & 48 \\
\hline 25 & 6 & 6 & 0 & 5 & 17 \\
\hline 35 & 8 & 1 & 2 & 5 & 16 \\
\hline 計 & 28 & 22 & $\begin{array}{ll}11 \\
\end{array}$ & 20 & 81 \\
\hline
\end{tabular}

